\title{
Protection of Children as Victims of Terrorism Crimes
}

\author{
Vience Ratna Multiwijaya ${ }^{1}$ \\ \{vienceratna@yahoo.co.id ${ }^{1}$ \} \\ Faculty of Law, Trisakti University, Jakarta, Indonesia ${ }^{1}$
}

\begin{abstract}
Incidents of riots in the Mako Brimob Detention Center and a series of terror incidents that occurred in Surabaya and surrounding areas involving minors. This is contrary to the Child Protection Act. In one of the rights the child provides special protection to the child victims of terrorism, both directly and indirectly. While what is meant by victims according to Arif Gosita are those who suffer physically and spiritually as a result of the actions of others who seek fulfilment of their own or others' interests that are contrary to interests and human rights. Terrorism is an alternative that radical organizations can choose to fight against ideology or a country that is considered to create injustice to certain groups of people in society and nation. Terrorism is specifically designed to cause fear that outside the target or victim. The main problem is "How is Legal Protection for Children victims of terrorism?" The research method uses normative research, with secondary data and analysed qualitatively. Protection of children victims of terrorism is necessary for rehabilitation, compensation or restitution, protection from identity reporting through the mass media and fulfilment of basic rights of religious education in schools are included in the correct learning curriculum and reinforcement of family resilience and awareness.
\end{abstract}

Keywords: Protection of Children, Victims, Terrorism Crimes

\section{Introduction}

\section{Background}

The incident of riots in Marko Brimob Detention House and bombing in three Surabaya Churches was widely criticized. In the incident, the bombing involved minors. This is very concerned, because the child is the next generation of the nation and the State that must be protected. In this case, the Government must pay attention to the implementation of the basic rights of children according to Article 59 paragraph 2 letter $\mathrm{H}$ Law No. 35 of 2014 regulates special protection for children victims of terrorism. The occurrence of terrorism involving children encourages National Police Chief Gen. Tito Karnavian to urge the government to immediately revise the Law on the Eradication of Criminal Acts of Terrorism (Law Number 15 of 2003). ${ }^{1}$ In addition, the theoretical law does not regulate the legal protection of children involved in terrorism. Changes to terrorism law are also expected to provide changes to children involved as perpetrators and victims of terrorism. The radicalism process carried out by terrorists must be stopped. Terrorism is carried out by radical organizations to take opposition to ideologies or countries that are considered to create injustice to certain groups of people in society and

\footnotetext{
${ }^{1}$ https://news.detik.com/kolom/d-4025271/perlindungan-dan-hak-korban-terorisme
} 
nation. Terrorism is specifically designed to cause fear. Terrorism is different from other forms of crime. Although using the same method by means of violence such as kidnapping, shooting, even victims suffer the same physical, mental and economic suffering. But the purpose of criminal acts of terrorism and general crime is very different. Based onKoespramono in the act of terrorism has the aim of using violence to achieve political goals by intimidating so that:

1. Receive recognition and attract attention through violent incidents

2. To draw attention to those who approve the method of terrorism that there is a reliable force

3. Want to master the government with the aim of supervising the State and the people. ${ }^{2}$

With the development of terrorism, the purpose of terrorism is not only political life but has penetrated, damaged and destroyed human life, which is damaging economic activity. The way terrorists who use explosives in the form of bombs is a serious threat to all nations, an enemy for all religions, and can occur throughout the world. Threats can disturb security and order which can threaten national security and stability, which is carried out by establishing a network of terrorism networks. The resulting consequences can result in victims of all levels of adults, adolescents and even young children. Acts of terrorism are now undergoing changes by involving children as perpetrators, as happened at the time of the bombing of three churches in Surabaya. The perpetrators consisted of one family headed by DitaOepriarto (47), the wife of PujiKuswanti (43), and also the perpetrators of their children Yusuf Fadhil (18), Firman Halim (16), Fadhila Sari (12) and FamelaRizqita (9). The involvement of children as perpetrators according to KPAI is an act that is not humanitarian in nature. The child has been given indoctrination of radicalism by the family. Child involvement in terrorism, according to Minister of Education and Culture Muhadjir Effendy, children of both perpetrators and victims are victims of criminal acts of terrorism. The inclusion of children is a new mode as a result of parents' ambition by misleading children. The impact of criminal acts of terrorism is not only global or worrying about a nation. But the impact is also felt by other nations in the world.

Therefore "the UN since September 8, 2006 formulated the Global Counter = Terrorism Strategy which contains 4 pillars, namely:

1. Addressing the conducive to the spread of terrorism

2. Preventing and combating terrorism

3. Building States capacity and strengthening the role of UN

4. Ensuring Human nights and the rule of Law. ${ }^{3}$

Children who are involved as terrorists are feared after adulthood, the child becomes terrorism. The government in this right must immediately take action to save the children of the nation in order to present successors of good quality people not as perpetrators of terror or acts of terrorism. In accordance with Article 76 of Law No. 23 of 2002 concerning Child Protection, the Indonesian Child Protection Commission (KPAI) must play an active role in disseminating legislation relating to child protection, supervising supervision of child administrators. One of the manifestations is that children of terrorism who are involved by the parents must be protected by observing the principle of restorative

\footnotetext{
${ }^{2}$ Koespramono Irsan, Terorism, ISSN Police Study Journal 0216 2563, Edition 057 July September 2003, Jakata p. 3

${ }^{3} \mathrm{http} / / /$ kompasiana.com//stevengalileo7994/5b164a26fPROTECTEDe7461f80/protect children of terrorists protecting children from perpetrators of terrorism
} 
justice in accordance with Law Number 11 of 2012 concerning the Criminal Justice System of Children. This is also in accordance with the legal principle of child protection that best interests for children and deprivation of liberty and punishment as a last resort. While parents and adults who involve children who must be convicted are even given a criminal weight according to Article 76 B of Law Number 35 of 2014 that everyone is prohibited from placing, letting, involving, ordering children to engage in situations of wrong treatment and neglect. If that happens then according to Article $77 \mathrm{~B}$ can be subject to a maximum imprisonment of 5 years and a maximum fine of $\mathrm{Rp} \mathrm{100,000,000} \mathrm{(one}$ hundred million rupiahs). In this context, special protection is needed for children who are terrorists and terrorism victims, both in child protection law and legislation on terrorism.

a. Formulation of The Problem

In relation to child terrorism and victims of terrorism, the subject matter to be discussed is "What is the legal protection of children of terrorism and victims of terrorism?"

b. Protection of the Children as Terrorist Crimes

A child is someone who is not yet 18 years old including a child who is still in the womb (Article 1 number 1 of Law Number 35 of 2014). Even children as weak parties must get protection from the State, Government, Regional Government, Community and Parents / guardians are obliged and responsible for the implementation of Child protection (article 20). The definition of child protection is all activities to guarantee and protect children and their rights to live, grow, develop and participate optimally in accordance with human dignity and dignity and to be protected from violence and discrimination. In carrying out the duty of protection, the protection is provided in an integrated manner, which means that regardless of ethnicity, religion, race, gender, ethnicity, culture and language, the legal status of the birth order and physical condition and / or mentoring 21).

The involvement of children as terrorists is a criminal act that can be subject to criminal sanctions both against the perpetrator. The meaning of a criminal act according to Simon is that an act (doing or not acting) that is subject to sanctions and is against the law is carried out by a person who is capable of being responsible and done with errors. Van Hamel defines a criminal act as a human act that is unlawful and committed with wrongdoing and deserves to be punished. ${ }^{4}$

The meaning of the word "terrorism" comes from the word 'to terror', in English, which means to tremble or vibrate. In the Big Dictionary, Indonesian language defines terror as an attempt to create fear, horror and cruelty by a person or group. C. Manullang interpreted terrorism as a way to seize power from other groups, triggered by many things, such as religious (ideological), ideological, ethical, economic inequality, understanding and community communication with the government or because of separatism and fanaticism ideology. ${ }^{5}$ Whereas the meaning of terrorism revised Law No. 15 of 2003 concerning the Eradication of Criminal Acts of Terrorism is an act that uses violence or the threat of violence that creates a widespread atmosphere of terror or fear, creates mass casualties, and / or causes damage or destruction to strategic vital objects, environment, public facilities or

\footnotetext{
${ }^{4}$ Soedarto, Revisi Edition of Criminal Law 1, Semarang, Sudarto Foundation, , 2013, hal 68

${ }^{5}$ Manullang A.C.Reveals Terror Intelligence Taboo, Motives and Regime, Jakarta :Panta Rhei, 2001, hal. 10
} 
international facilities, with ideology, political motives or security disturbances. Based on this definition, the elements of criminal acts of terrorism "every form of use of violence that causes widespread fear or causes victims who have mass membership".

The involvement of children in criminal acts of terrorism is a new model as happened in the bombing case of three churches in Surabaya. This is clearly very dangerous because children are the next generation of a nation. Children who should have the right to grow and develop according to the principle of child protection is the interest for the sake of children ${ }^{6}$. Children are born as adults have the right to basic rights and every anal born with white and holy.

Chidren can become perpetrators, there are several factors, including environmental factors, economic and social factors. One of the enviromental factors is the family in the case the parents ${ }^{7}$. The family is the main unit responsible for the socialization of juvenile deliquency.The child must be a criminal. Children are born as well as basic rights as adults and each child is white and holy. The parents are responsible for shaping the character, mentality, principles and choices of the child's life view. This social environment influences the life of children. This is very unfortunate since childhood the child has been filled with the understanding or teachings of the doctrine of violence and intolerance by involving children with violence and acts of terrorism. Obviously, this method raises concerns about the child's future. Therefore, there must be special protection from the government. Even according to the Witness and Victim Protection Agency children of terrorists are victims of parental behavior.

The meaning of children according to several laws and regulations:

1) Article 1 number 1 of Law No. 23 of 2014 is a person who has not had 18 years of age including a child in the womb.

2) UU no. 11 of 2012 concerning the Criminal Justice System of Children, children in conflict with the law, called children are children who are 12 years old but not yet 18 years of age who are suspected of committing a crime. Whereas children facing the law are children who are in conflict with the law, children who are victims of criminal acts and children who are witnesses of criminal acts

3) Law Number 15 of 2003, does not explicitly explain what the child means, but in Article 19 contains provisions that impose a special minimum crime in Article 6, Article 8, Article 9, Article 10, Article 11, Article 12, Article 13, Article 15, Article 16, and the provisions concerning capital punishment or life imprisonment as referred to in Article 14, do not apply to perpetrators of terrorism who are under 18 years of age.

Crime of terrorism committed by children with adults in the case of criminal imposition must be different. In Article 18 of Law No. 23 of 2002 regulates that every child who is a victim or a criminal is entitled to legal assistance or other assistance. This is corroborated by Article 59 paragraph 2 that special protection is given to victims of terrorism networks. Therefore, the handling of the legal process against children in criminal acts of terrorism must be based on Law Number 11 of

${ }^{6}$ M. Nasir Djamil, Children Not To Be Sentenced, Jakarta, Sinar Grafika, 2012,hal 30

7 A. Syamsudin Meliala dan E. Sumaryono, Child Review and Psychological, Exixtence and Implications, , Yogyakarta, Liberty, hal. 31 
2012 concerning the Criminal Justice System of Children by prioritizing a restorative justice approach (Article 5). Besides that, the process of investigating until a criminal imposition must pay attention to the provisions of a child aged 14 years and over and allegedly committing a crime with a threat of 7 years and above.

Against the criminal that can be handed down by a judge must pay attention to Article 71 of Law No. 11 of 2012, namely:

(1) Principal Crimes for Children consist of:

a. Commemorative warning

b. Criminal terms:

1. Coaching outside the institution

2. Community service

3. Supervision

c. Job training

d. Coaching in institutions

e. Prisons

(2) Additional Crimes consist of:

a. deprivation of profits obtained from a criminal act or

b. fulfillment of customary obligations

In the case of imprisonment of a child the offender must pay attention

a. Article 81:

1. The child is sentenced to imprisonment in the Child Correctional Institution (LPKA) if the child's circumstances and actions endanger the community

2. Criminal imprisonment can be imposed on the child no later than $1 / 2$ of the maximum threat of imprisonment for adults

3. Criminal imprisonment is only used as an effort last

b. Article 60:

(1) Judges are obliged to consider social research reports from Community Counsel before making a case decision

(2) In the event that a social research report is not considered in a judge's decision, the decision is null and void. As for the reasons for the involvement of children in becoming a criminal act of terrorism are:

1. Doctrine of obedience

Children must submit and obey parents. Because parents feel as assets that can be treated anything. Parents who play a role in shaping their future lives, education and social life.

2. Theological View

In this view, it is taught that they must enter Surge together so that children must help their parents in realizing the crime of terrorism

3. Victims of terrorism do not think children will be able to act as sadly as

In accordance with the Theory of Development Law from Mochtar Kusumaatmadja, that law as a tool becomes a means to build society. By Romli the theory of Mochtar Kusumaatmadja put forward the key to this theory which is to guarantee changes that occur in an orderly way through the help of legislation, court decisions and both.terrorism so that prevention is not directed against children of 
terrorists ${ }^{8}$. Especially for the issue of terrorism in accordance with the aim of the theory of development law in order to create order in society, there will be a change to Law Number 15 of 2003 into Law Number 5 of 2018. Particularly the meaning of terrorism acts Article 1 number 2 is an act that uses violence or threats of violence that creates an atmosphere widespread terror or fear, which can cause mass casualties, and or cause damage, or strategic destruction of objects, environment, public facilities, or international facilities with ideological, political or security disturbances.

Jeremy Bentham as a Classical stating that criminality was imposed on to prevent crime, guarantees criminals no longer commit crimes by guiding criminals in carrying out punishments. This is in accordance with the principle of determinism which requires the existence of criminal individualization with the aim of holding resocialization of perpetrators ${ }^{9}$

Base on this, children who are involved in terrorism do not know what is being done is at high risk. In other words, children of theorist are victims of parental sacrifice. Children who are involved in terrorism in the case of imposing criminal sanctions must pay attention to the provisions of Article 81 paragraph 6 of Law No. 11 of 2012, a criminal offense that is subject to a death sentence or life imprisonment, a criminal that can be imposed is a sentence, and a maximum of 10 years in prison. This is in accordance with Article 19 of Law No. 15 of 2003 that capital punishment or life imprisonment as referred to in Article 14 does not apply to perpetrators of criminal acts of terrorism under the age of 18 years. Criminal provisions for the offender's child are appropriate. Even the Witness and Victim Protection Agency explicitly said that children of terrorists are victims of parental behavior.

Legal protection provided to children who are victims of criminal acts must cover all aspects of both the principle and purpose of protection for the best interests of the child, life and growth, avoid violence and discrimination in order to realize quality, moral, noble and prosperous Indonesian children. Rights of rights that must be considered:

a. Law Number 23 years 2002

Article 13

(1) Every child has the right to protection from treatment:

a. Discrimination

b. Economic and sexual exploitation

c. Abandonment

d. Cruelty, violence and persecution

e. Injustice 'wrong treatment

Article 15:

Have the right to get protection from

a. Abuse in political activities

b. Engagement in armed disputes

c. Engagement in social unrest

d. Engagement in violent events

${ }^{8}$ Shidarta (ed), Mochtar Kusumaatmadja and Legal Theory of Development, Exixtence and Impications, Jakarta, Epiterna Huma, 2012, pl. 13

${ }^{9}$ Muladi dan Badra Nawawi Arief, Theory of Criminal Policy Theory, Cet II, Bandung, Alumni, 1998, p. 32,39 
e. War fund involvement

Article 16:

(1) Every child has the right to receive protection and targets of mistreatment, torture, or imposition of inhuman penalties.

(2) Every child has the right to obtain freedom in accordance with the law

(3) Arrests, detention or criminal acts of child prisons are only carried out if they are in accordance with the applicable law and can only be carried out as a last resort

Article 17 Law Number 23 years 2002

(1) Every child deprived of his liberty has the right to:

a. Get humane treatment and placement separated and adults

b. Obtain legal assistance and help others effectively at each stage of the applicable effort

c. Defend yourself and obtain justice before an objective and impartial child court in a closed session for the public

(2) Every child who is a victim or perpetrator of sexual violence or who is dealing with a law that must have an identity is kept confidential

With regard to the protection of children, specifically concerning children with criminal acts of terrorism, there are obligations from the Government, Regional Governments and other State institutions to provide special protection to children such as children in the network of theorists, children with deviant social behavior and children who are victims of stigmatization and labeling are related to parental conditions (Article 59 of Law Number 35 of 2014). As for Article 59 A of Law Number 35 of 2014, special protection is given through:

a. Quick handling including physical and psychological treatment and / or rehabilitation, and prevention of diseases and other health disorders

b. Psychosocial assistance during treatment until recovery

c. Providing social assistance to children from disadvantaged families

d. Provision of protection and assistance in every court process

Article 69 B of Law Number 35 of 2014, special protection for children victims of terrorism networks is passed through efforts:

a. Education about education, ideology and nationalism values

b. Counseling about the dangers of terrorism

c. Social rehabilitation

d. Social assistance

Children who are involved in terrorism in the case of imposing criminal sanctions must pay attention to the provisions of Article 81 paragraph 6 of Law No. 11 of 2012, a criminal offense that is subject to a death sentence or life imprisonment, a criminal that can be imposed is a sentence, and a maximum of 10 years in prison. This is in accordance with Article 19 of Law No. 15 of 2003 that capital punishment or life imprisonment as referred to in Article 14 does not apply to perpetrators of criminal acts of terrorism under the age of 18 years. Criminal provisions for the offender's child are appropriate. This is caused by the child terrorism perpetrators do not know what he will do has a big risk. In other words, children are victims of parents. Even the Witness and Victim Protection Agency explicitly said that children of terrorists are victims of parental behavior. In Article $16 \mathrm{~A}$, every person who 
commits a criminal act of terrorism by involving a child with a criminal threat plus one third.

Children as victims of acts of terrorism before the revision of Law No. 15 of 2003 only contains 2 things, namely compensation and restitution. In the revision of Law No. 15 of 2003 added 4 additional articles as victims 'rights (Article $35 \mathrm{AB}$ and Article $36 \mathrm{AB}$ ), so that the victims' rights were six in the form of medical assistance, psychological rehabilitation, psychosocial rehabilitation, compensation for dead victims, this right is granted shortly after a criminal act of terrorism is carried out by the witness protection agency and the victim can cooperate with relevant agencies or institutions, and give restitution and compensation provided by the perpetrator to the victim and his heirs.

Law No. 31 of 2014 concerning Witness Protection and victims also contains safeguards for victims of acts of terrorism which are regulated in:

a. Article 5:

(1) Witnesses and victims are entitled:

a. Obtain protection for personal, family and property security and be free from threats relating to the testimony that will, is or has been given

b. Participate in the process of selecting and determining forms of security protection and support

c. Provide information without pressure

d. Get a lecturer

e. Free of trapping questions

f. Get information about the case

g. Get information about court decisions

h. Get information in case the convict is released

i. Confidential identity

j. Get a new identity

k. Get a temporary residence

1. Got a new residence

$\mathrm{m}$. Obtain temporary living expenses assistance until the protection deadline expires and / or

n. Get assistance

(2) The right in paragraph (1) is given to witnesses and / or victims of criminal acts in certain cases in accordance with the decision of the witness and victim protection agencies

b. Article 6:

(1) Victims of severe human rights violations, victims of acts of terrorism, victims of trafficking in persons, victims of criminal acts of torture, victims of crimes of sexual violence and victims of severe abuse, in addition to the right as intended in Article 5, also entitled to:

a. Medical assistance

b. Psychosocial and psychological rehabilitation assistance

(2) Assistance under paragraph (1) is given based on the decision of the witness and victim protection agencies

c. Article 7 
(1) Every victim of severe human rights violations and victims of terrorism in addition to obtaining rights as Article 5 and Article 6 are also entitled to compensation

(2) Compensation for victims of gross human rights violations submitted by victims, families or their proxies to the human rights court through witness and victim protection agencies

(3) The payment of compensation is given by the witness and victim protection agencies based on a court decision that has obtained permanent legal force

(4) The granting of compensation for victims of acts of terrorism is carried out in accordance with the provisions of the law on regulations which regulate the elimination of criminal acts of terrorism.

d. Article 7A

(1) Victims of criminal acts get restitution in the form of:

a. Replace losses for loss of wealth or income

b. Replace damages resulting from suffering directly related to a crime and / or

c. Replacement of medical and / or psychological care costs

(2) Criminal acts in paragraph (1) are determined by witness and victim protection agencies decision

(3) Submission of applications for restitution can be done before or after a court decision that has obtained permanent legal force through witness and victim protection agencies

(4) In the event that a request for restitution is submitted before a court decision that has obtained legal force, LPSK can submit a Restitution to the public prosecutor to be included in the claim.

(5) In the event that a request for restitution is filed after a court decision that has obtained permanent legal force, LPSK may submit a Restitution to the court to obtain a determination

(6) In the right of the victim to die of a crime, restitution is given to the family of the victim who is the heir of the victim.

\section{Conclusion}

Legal protection given to children of terrorism perpetrators is regulated in Law Number 23 of 2002, calm Child Protection, Law Number 35 of 2014 concerning Amendments to Law Number 23 of 2002 concerning Child Protection, Law Number 15 of 2003 concerning the Eradication of Terrorism Crime and its revision, and Law Number 31 of 2014 concerning Protection of Witnesses and Victims. The forms of legal protection for children with criminal acts of terrorism include:

a. Obtain compensation and restitution.

b. in the form of medical assistance, psychological rehabilitation,

c. psychosocial rehabilitation, compensation for death victims

d. not sentenced to death or life sentence for children under the age of 18

e. Child identity must be kept secret in mass media reporting 
f. Education about education, ideology and nationalism values

g. Counseling about the dangers of terrorism

\section{Reference}

[1]. Zen PM. Perlindungan dan Hak Korban Terorisme. 2018. Cited on: September $3^{\text {rd }}, 2018$. Available from: https://news.detik.com/kolom/d-4025271/perlindungan-dan-hak-korbanterorisme

[2]. Koespramono I. Terorism. Police Study Journal. 2003;57:3-30

[3]. Soedarto. Revised Edition of Criminal Law I. Semarang. Sudarto Foundation. 2013. p68

[4]. Manullang AC. Reveals Terror Intelligence Taboo, Motives and Regime. Jakarta. Panta Rhei. 2001. p10

[5]. Djamil MN. Children Not To Be Sentenced. Jakarta. Sinar Grafika. 2012. P30

[6]. Meliala AS, Sumaryono E. Child Review and Psychological, Existence and Implications. Yogyakarta. Liberty. 2010

[7]. Shidarta, Kusumaatmadja M. Legal Theory of Development, Existence and Implications. Jakarta. Epitema Human. 2012. p19.

[8]. Muladi, Arief BN. Theories of Criminal Policy. Ed II. Bandung. Alumni. 1998. p 32-39

[9]. Law Number 23 of 2002 concerning Child Protection

[10]. Law 35 of 2014 concerning Amendments to Law Number 23 of 2002 concerning Child Protection

[11]. Law Number 5 of 2018 concerning Amendments to the Law Number 15 of 2003 concerning

[12]. Determination of the Substitute Government of the Republic of Indonesia Law No. 1 of 2002 concerning the Eradication of Terrorism Crimes into Law 